\title{
Acacia hydaspica R. Parker prevents doxorubicin-induced cardiac injury by attenuation of oxidative stress and structural Cardiomyocyte alterations in rats
}

Tayyaba Afsar ${ }^{1 *}$, Suhail Razak²,3, Khalid Mujasam Batoo ${ }^{4}$ and Muhammad Rashid Khan ${ }^{1}$

\begin{abstract}
Background: The use of doxorubicin (DOX) an anthracycline antineoplastic agent is withdrawn due to its cardio-toxic side effects. Oxidative stress has been recognized as the primary cause of DOX induced cardiotoxicity. We have investigated whether polyphenol rich ethyl acetate extract of Acacia hydaspica (AHE) can attenuate doxorubicin-induced cardiotoxicity via inhibition of oxidative stress.

Methods: AHE was administered orally to rats once daily for 6 weeks at doses of 200 and 400 mg/kg b.w. DOX ( 3 mg/kg b.w. i.p., single dose/week) was administered for 6 weeks (chronic model). The parameters studied to evaluate cardioprotective potential were the serum cardiac function biomarkers (CK, CKMB, AST and LDH), hematological parameters, cardiac tissue antioxidant enzymatic status and oxidative stress markers, and histopathological analysis to validate biochemical findings.

Results: Chronic 6 week treatment of DOX significantly deteriorated cardiac function biomarkers and decreased the activities of antioxidant enzymes, whereas significant increase in oxidative stress biomarkers was noticed in comparison to control group. AHE dose dependently protected DOX-induced leakage of cardiac enzymes in serum and ameliorated DOX-induced oxidative stress; as evidenced by decreasing lipid peroxidation, $\mathrm{H}_{2} \mathrm{O}_{2}$ and $\mathrm{NO}$ content with increase in phase I and phase II antioxidant enzymes. Doxorubicin treatment produced severe morphological lesions, leucopenia, decrease in red blood cell counts and hemoglobin concentrations. AHE co-treatment protected the heart and blood elements from the toxic effects of doxorubicin as indicated by the recovery of hematological parameters to normal values and prevention of myocardial injuries in a dose dependent way. The protective potency of AHE (400 mg/kg b.w) was equivalent to silymarin.
\end{abstract}

Conclusion: Results revealed that AHE showed protective effects against DOX induce cardiotoxicity. The protective effect might attribute to its polyphenolic constituents and antioxidant properties. AHE might be helpful in combination therapies as safer and efficient.

Keywords: Doxorubicin, Cardiotoxicity, Oxidative stress, Cardiac function biomarkers, Antioxidants, Polyphenolics

\footnotetext{
* Correspondence: tayyaba_sona@yahoo.com

${ }^{1}$ Department of Biochemistry, Faculty of Biological Sciences, Quaid-i-Azam

University, Islamabad, Pakistan

Full list of author information is available at the end of the article
} 


\section{Background}

Cardiovascular disease (CVD) is the second leading cause of long-term morbidity and mortality among cancer survivors. Conventional chemotherapy and targeted therapies are associated with an increased risk of myocardial dysfunction to irreversible heart failure or even death [1]. The anthracycline anticancer drug doxorubicin (DOX) also recognized as adriamycin, is an effective and frequently used chemotherapeutic agent for various malignancies [2-6]. Regardless of its great antitumor efficiency, its use in chemotherapy is limited due to its varied side effects. Its most prevalent and unavoidable side effect is cardiotoxicity $[5,7,8]$. DOX administration outcomes in permanent cardiomyopathy even lapse of years after the completion of chemotherapy [9-11]. Even when taking into account lower cumulative doses and cardioprotective regimens now in use, DOX cardiotoxicity still occurs, and its prevention and management remains of concern to both cardiologists and oncologists. There appears to be multifactorial patho-mechanisms behind DOX-associated late cardiotoxicity, but predominantly oxidative stress is linked to redox cycling of the drug due to the overproduction of superoxide radicals $\left(\mathrm{O} 2-{ }^{-}\right)$; which is the source for generating hydrogen peroxide and much more toxic hydroxyl radical and hence inducing oxidative stress [12-14]. Most the reactions involved in the DOX radical generation were catalyzed in the liver instead of heart, but due to relatively low antioxidant defense of cardiomyocytes makes the heart a most prominent target for DOX toxicity and the extent of the doxorubicin-persuaded oxidative trauma is up to 10 times higher in the cardiac tissue as compared to other tissues (liver, kidney, spleen). Structural cardiomyocyte alterations and cell death induced by DOX is mediated in part by reactive oxygen species (ROS) generated in iron-dependent chemical reactions. ROS lead to the peroxidation of myocyte membranes and, after calcium influx, into the intracellular space, which can ultimately lead to permanent myocyte damage [15].

Over the years, researchers have testified that plants containing phenolics and flavonoids exhibit a large array of biological activities including cardio-protection, antifibrosis and anticancer [16, 17]. Cardiotoxicity associated with DOX treatment has been successfully prevented by different medicinal plants with antioxidant activity. Thus, it is well justified to explore more plant derivednatural compounds that inhibit the cardiotoxicity of DOX and improve its chemotherapeutic efficiency $[18,19]$.

Acacia species are rich sources of polyphenolic compounds, known to have strong antioxidant properties that help in the prevention of various oxidative stress related diseases including cardiovascular, neurodegenerative and cancer [20-22]. Acacia hydaspica R. Parker; synonym A. eburnea belongs to family Leguminosae [23], possesses antioxidant, anticancer, anti-hemolytic, antiinflammatory, antipyretic, analgesic and antidepressant potentials. These activities might attribute to the presence of various active secondary metabolites i.e. gallic acid, catechin, rutin, caffeic acid, 7-O-galloyl catechin, +catechin and methyl gallate [24-26]. Polyphenolic compounds isolated from A. hydaspica induce apoptosis and inhibit various pro-survival signaling pathways in breast and prostate cancer cell lines, indicating their potential in molecular target based adjuvant chemotherapy [27]. Ethyl acetate extract of $A$. hydaspica (AHE) was selected for the current investigation due to its significant antioxidant capacity [26], and the presence of catechin and gallic acid as chief component, substantial total phenolic and flavonoid content (Table 1). Previous researches indicated that catechins possess persuasive antioxidant, anti-inflammatory, immunomodulatory, cardioprotective, and anticancer potentials. Catechin showed cardioprotective effects in rats and ameliorated electrocardiogram (ECG) changes and myocardial contractility. The underlying mechanisms involved in the cardioprotective effects of catechin could be attributed to its antioxidant and anti-apoptotic activities [28]. Acacia species have also been tested in animal models to evaluate their cardioprotective potential. A. Senegal Gum Arabic showed potential protective effects against doxorubicininduced cardiotoxicity by reducing Dox induced cardiac tissue damages and reducing altered serum biomarkers in rats [29]. Another study in rabbits indicated that $A$. senegal seed extract administration ameliorated atherogenic diet induced cardiac LPO and histopathological abnormalities in aorta wall, heart and kidney.

Based on earlier research on the cardio-protective potential of the Acacia species, polyphenolic compounds in animal models and antioxidant properties of $A$. hydaspica; current investigation was done to determine the potential of ethyl-acetate extract of $A$. hydaspica to attenuate DOXinduced cardiac toxicity and oxidative stress in rats. In this regard the activity level of various antioxidant enzymes of cardiac tissues, histopathological evaluation along with biochemical serum cardiac function markers and hematological parameters were investigated to evaluate the protective potential of $A$. hydaspica against DOX induced cardiac damages.

\section{Methods}

Plant collection and preparation of AHE extract

Aerial parts (bark, twigs, and leaves) of A. hydaspica were collected from Kirpa charah area Islamabad, Pakistan. Plant specimen was identified by Dr. Sumaira Sahreen (Curator at Herbarium of Pakistan, Museum of Natural History, Islamabad). Plant specimen with Accession No. 0642531 was deposited at the Herbarium of Pakistan, Museum of Natural History, Islamabad. A. hydaspica methanol extract was fractionated as previously 
Table 1 Extraction yield, TPC, TFC, and chemical constituents in A. hydaspica ethyl acetate extract (AHE)

\begin{tabular}{|c|c|c|}
\hline Analysis (AHE fraction) & Observations & (References) \\
\hline Extraction yield (\%) & $27.77 \%$ & [25] \\
\hline TPC (mg gallic acid equivalent/g dry sample) & $120.3 \pm 1.15$ & [25] \\
\hline TFC (mg rutin equivalent/g dry sample) & $129 \pm 1.32$ & [25] \\
\hline \multirow{3}{*}{$\begin{array}{l}\text { HPLC-DAD (Identification of compounds } \\
\text { with reference to standards) }\end{array}$} & i. Gallic acid (275 nm, RT: 4.516, $52.92 \mu \mathrm{g} / 100 \mathrm{mg}$ dry powder) & \multirow[t]{3}{*}[25]{} \\
\hline & ii. Catechin (279 nm, RT 11.427, 8648 g/100 mg dry powder) & \\
\hline & iii. Myricetin (368 nm, RT: 17.082, 34.60 mg/100 mg dry powder) & \\
\hline \multirow{3}{*}{$\begin{array}{l}\text { Purified isolated compounds } \\
\text { (NMR characterization of compounds) }\end{array}$} & i. 7-O-galloyl catechin (GC)(187.5 mg/g) & \multirow[t]{3}{*}[24,27]{} \\
\hline & ii. Catechin (C), (100 mg/g) & \\
\hline & iii. Methyl gallate (MG), (37.5 mg/g) & \\
\hline
\end{tabular}

TPC Total Phenolic content, TFC Total flavonoid content

Information derived from previous lab investigations

described [25], and its ethyl acetate extract (AHE) (the most bioactive extract under in vitro examinations and containing bioactive polyphenols [27]) was selected for further in vivo investigation.

\section{Drug and plant dose preparation}

Doxorubicin (DOX) injection was obtained from SigmaAldrich (St. Louis, MO, U.S.A.) and dissolved in saline to make appropriate dose for administration. An entire doxorubicin dose of $18 \mathrm{mg} / \mathrm{kg}$ body weight was inoculated to rats during the experimental period [30]. Silymarin (100 mg/kg b.w) and AHE (400 and $200 \mathrm{mg} / \mathrm{kg}$ b.w) were freshly prepared in distilled water before dosing [31].

\section{Ethics statement}

Animals were cared for in accordance with the standard guidelines of national institute of animal health (NIH guidelines) to conduct the experiment effectively. The protocol was approved by the Ethics Committee of Animal Care and Use at Quaid-i-Azam University, Islamabad (Approval No.Bch\#264).

\section{Experimental animals}

Male Sprague Dawley rats (200-225 g) were kept in the Primate Facility at Quaid-i-Azam University, Islamabad. Animals were acclimatized for 7 days to laboratory conditions. The animals were placed in conventional steel cages at room temperature, fed with standard pellet diet and tap water under $12 \mathrm{~h} \mathrm{light/dark} \mathrm{cycle} \mathrm{at} 25 \pm 3{ }^{\circ} \mathrm{C}$.

\section{Acute toxicity evaluation}

The acute toxicity study was conducted as per the guidelines 425 of Organization for Economic Cooperation and Development (OECD) for testing of chemicals for acute oral toxicity [32]. Male Sprague Dawley rats were kept in fasting conditions for overnight with just water availability. Three animals were orally administered with dose-of $50 \mathrm{mg} / \mathrm{kg}$ bw and were monitored for mortality rate for
$72 \mathrm{~h}$. No initial progression of toxicity was observed, but the methodology was subsequently followed with augmented amount of oral doses i.e., 100, 200, 400, 1000, 2000, 3000 and $4000 \mathrm{mg} / \mathrm{kg}$ bw of AHE, while the control group received saline $(10 \mathrm{ml} / \mathrm{kg})$. Three animals were used for each treatment. General behavioral changes were detected by the previously described procedure [33]. Animals were observed continuously for $2 \mathrm{~h}$ and parameters which were observed were convulsion, tremor, aggression, excitation, loss of grasp, altered reactivity to touch, and sedation [34]. AHE was found to be safe at all tested doses (up to $4000 \mathrm{mg} / \mathrm{kg} \mathrm{b.w}$ ) and it did not induced any noxious symptom in rats like sedation, convulsions, diarrhea and irritation. 200 and $400 \mathrm{mg} / \mathrm{kg}$ bw doses were selected for the evaluation of cardioprotective activity.

\section{Treatment regime}

The study protocol was designed according to previous studies [35-37] with slight modifications. Animals were randomly divided into six groups $(n=6)$ and were subjected to following treatments.

Group I: Control; received six doses of normal saline (0.4 ml, i.p.) for 6 weeks (one dose/week) and distilled water oraly for 6 weeks.

Group II: DOX treated; received $3 \mathrm{mg} / \mathrm{kg}$ b.w. (i.p.) dose of DOX, one dose per week for 6 weeks $(18 \mathrm{mg} /$ $\mathrm{kg}$ b.w. total dose) for inducing organ toxicity, and oral distilled water for 6 weeks.

Group III: AHE treated; received a single oral dosage of $400 \mathrm{mg} / \mathrm{kg}$ b.w. /day for 6 weeks.

Group IV: DOX+ AHE $200 \mathrm{mg} / \mathrm{kg}$; received a single oral dose of $200 \mathrm{mg} / \mathrm{kg}$ b.w. /day for 6 weeks with DOX i.p. injection once per week.

Group V: DOX+ AHE $400 \mathrm{mg} / \mathrm{kg}$; received one dose of $400 \mathrm{mg} / \mathrm{kg}$ b.w., p.o. /day for 6 weeks with DOX i.p. injection once per week. 
Group VI: DOX+ Silymarin; received 2 oral doses of $100 \mathrm{mg} / \mathrm{kg}$ b.w/ week (12 doses/6 weeks) with DOX i.p. injection once per week.

Initial and final body weights of rats were recorded.

\section{Sample preparation}

Animals were euthanized by cervical dislocation and dissected from ventral side. Blood was collected and centrifuged at $10,000 \mathrm{rpm}$ for $15 \mathrm{~min}$ at $4{ }^{\circ} \mathrm{C}$ to obtained serum. Serum samples were kept in a freezer at $-80{ }^{\circ} \mathrm{C}$ for subsequent biochemical analysis. After taking blood, the heart was removed and washed in ice cold saline and weigh. Subsequently, half of the organs were treated with liquid nitrogen and stored at $-80{ }^{\circ} \mathrm{C}$ for further enzymatic analysis while the other half was processed for histology.

\section{Cardiotoxicity indices}

Different cardiac marker enzymes were used to perform the cardiac function tests such as aspartate aminotransferase (AST), creatine kinase (CK) and creatine kinase$\mathrm{MB}$ (CK-MB) and lactate dehydrogenase (LDH) activities were estimated in serum samples by the standard procedure of AMP diagnostic kits (Stattogger Strasse 31b 8045 Graz, Austria).

\section{Hematological parameters}

Heparinized blood samples were used for the evaluation of hematological parameters. Amount of red blood cells (RBCs), white blood cells (WBCs), platelets, hemoglobin concentration $(\mathrm{Hb} \%)$, mean corpuscle volume (MCV), packed cells volume (PCV), mean corpuscle hemoglobin $(\mathrm{MCH})$, hematocrit value (HTC), mean corpuscle hemoglobin concentration (MCHC), neutrophils and lymphocytes were examined following standard methods using an automated analyzer (Mindray Auto hematology Analyser BC-5500).

\section{Biochemical studies of heart}

Homogenate preparation $100 \mathrm{mg}$ of heart tissue was homogenized in 10 volumes of $100 \mathrm{mM} \mathrm{KH} 2 \mathrm{PO} 4$ buffer containing $1 \mathrm{mM}$ EDTA, $\mathrm{pH} 7.4$ and centrifuged at $12,000 \times \mathrm{g}$ for $30 \mathrm{~min}$ at $4{ }^{\circ} \mathrm{C}$. The supernatant was collected and used for the following experiments.

Estimation of tissue protein content Lowry et al. procedure was followed to estimate the total soluble proteins within the tissue samples [38]. To the tissue homogenate $200 \mu \mathrm{l}$ of $1.1 \mathrm{M}$ potassium phosphate buffer-( $\mathrm{pH} 8.0)$ was added to dilute the tissue sample. A volume of $1 \mathrm{ml}$ of alkaline copper-solution was added to-this blend, and placed at room temperature. After incubation for $20 \mathrm{~min}, 200 \mu \mathrm{l}$ of Folin-Ciocalteu phenol reagent was added. Reaction tubes containing the test mixtures were then vortexed and incubated again at $37^{\circ} \mathrm{C}$ for $20 \mathrm{~min}$. At $650 \mathrm{~nm}$ OD was measured spectrophotometrically. Total soluble proteins of the tissue samples were then detected using standard curve of bovine serumalbumin (BSA).

\section{Analysis of cardiac tissue antioxidant status}

Catalase (CAT) activity On the basis of decomposition of hydrogen peroxide CAT activity were analyzed by following the modified protocol of Khan et al. [39]. In brief, CAT reaction solution consists of $625 \mu \mathrm{l}$ of $50 \mathrm{mM}$ of potassium phosphate buffer ( $\mathrm{pH} 5), 100 \mu \mathrm{l}$ of $5.9 \mathrm{mM}$ $\mathrm{H}_{2} \mathrm{O}_{2}$ and $35 \mu \mathrm{l}$ enzyme extract, change in absorbance was noted for one minute at a wavelength of $240 \mathrm{~nm}$ by spectrophotometer. A change of 0.01 in absorbance for one minute was taken as one unit of CAT activity.

Peroxidase assay (POD) Activities of POD were evaluated based on guaiacol peroxidation [39]. POD reaction solution was prepared by adding $75 \mu \mathrm{l}$ hydrogen peroxide $(40 \mathrm{mM}), 25 \mu \mathrm{l}$ guaiacol $(20 \mathrm{mM})$, and $25 \mu \mathrm{l}$ of supernatant to $625 \mu \mathrm{l}$ of potassium phosphate buffer $(\mathrm{pH} 5.0,50 \mathrm{mM})$ in sequence. Change in absorbance of the reaction solution at $470 \mathrm{~nm}$ was observed for one minute. One unit POD activity is equivalent to change in absorbance of 0.01 as units/min.

Superoxide dismutase (SOD) activity Phenazine methosulphate and sodium pyrophosphate buffers were exploited for the assessment of SOD activity [40]. Centrifugation of tissue homogenate was done at $1500 \times \mathrm{g}$ for $10 \mathrm{~min}$ followed by $10,000 \times \mathrm{g}$ for $20 \mathrm{~min}$. $150 \mu \mathrm{l}$ supernatant was added to the reaction mixture containing $600 \mu \mathrm{l}$ of $0.052 \mathrm{mM}$ sodium pyrophosphate buffer ( $\mathrm{pH} 7.0$ ) and $186 \mathrm{mM}$ of phenazine methosulphate $(50 \mu \mathrm{l})$. To initiate enzymatic reaction $100 \mu \mathrm{l}$ of $780 \mu \mathrm{M}$ NADH was added. After $1 \mathrm{~min}$, glacial acetic acid $(500 \mu \mathrm{l})$ was added to stop the reaction. The color intensity was measured at wavelength of $560 \mathrm{~nm}$. Results were expressed in units/mg protein.

Quinone reductase assay (QR) The Quinone reductase activity was evaluated as described earlier [41]. $100 \mu \mathrm{l}$ of tissue homogenate was added to $3 \mathrm{ml}$ of a reaction mixture comprised of $2.13 \mathrm{ml}$ Tris- $\mathrm{HCl}$ buffer $(25 \mathrm{mM}$; $\mathrm{pH}$ 7.4), $700 \mu \mathrm{l}$ of BSA, $100 \mu \mathrm{l}$ of FAD, $20 \mu \mathrm{l}$ of NADPH $(0.1 \mathrm{mM})$. Reduction of dichlorophenolindophenol (DCPIP) was noted at $600 \mathrm{~nm}$. Enzyme potency was estimated as $\mathrm{nM}$ of DCPIP reduced $/ \mathrm{min} / \mathrm{mg}$ protein using molar extinction coefficient of $2.1 \times 10^{4} / \mathrm{M} / \mathrm{cm}$. 
Reduced glutathione (GSH) estimation test The concentration of reduced glutathione was assessed as described by Jollow [42]. The basis of this method-is based on the breakdown-of 1, 2-dithio-bis nitro-benzoic acid (DTNB) by sulfosalicylic acid, as a result yellow-color is produced. The yellow color produced was read immediately at $412 \mathrm{~nm}$ on a-spectrophotometer and was expressed as $\mu \mathrm{M}$ GSH/g tissue.

Glutathione-S-transferase (GST) Scheme of Habig et al. [43] was followed for the estimation of GST potency. The assay principle relies on the formation of CDNB conjugate. $150 \mu \mathrm{l}$ aliquot of tissue homogenate was added to $720 \mu \mathrm{l}$ of sodium phosphate buffer together with $100 \mu \mathrm{l}$ of reduced glutathione $(1 \mathrm{mM})$ and $12.5 \mu \mathrm{l}$ of CDNB (1 mM). OD was recorded at $340 \mathrm{~nm}$ by spectrophotometer. GST activity was estimated as amount of CDNB conjugate formed per minute per $\mathrm{mg}$ protein using molar coefficient of $9.61 \times 10^{3} / \mathrm{M} / \mathrm{cm}$.

Glutathione reductase assay (GSR) GSR activity was analyzed by following the method of Carlberg and Mannervik [44]. $100 \mu \mathrm{l}$ of supernatant samples were amalgamated with $1.65 \mathrm{ml}$ phosphate buffer: $(0.1 \mathrm{M}$; $\mathrm{pH}$ 7.6), $100 \mu \mathrm{l}$ EDTA $(0.5 \mathrm{mM}), 50 \mu \mathrm{l}$ oxidized glutathione $(1 \mathrm{mM})$ and $100 \mu \mathrm{l}$ NADPH $(0.1 \mathrm{mM})$. The OD was measured at $340 \mathrm{~nm}$ after mixing. Enzyme activity was estimated as nM NADPH oxidized $/ \mathrm{min} / \mathrm{mg}$ protein, using molar extinction coefficient of $6.22 \times 10^{3} / \mathrm{M} / \mathrm{cm}$.

Glutathione peroxidase assay (GSH-Px) Glutathione peroxidase activity was assessed as described previously [45]. $100 \mu \mathrm{l}$ supernatant samples were mixed with $100 \mu \mathrm{l}$ EDTA $(1 \mathrm{mM}), 1.49 \mathrm{ml}$ phosphate buffer $(0.1 \mathrm{M}$; $\mathrm{pH} 7.4), 100 \mu \mathrm{l}$ sodium azide $(1 \mathrm{~m} \mathrm{M}), 50 \mu$ l glutathione reductase $(1 \mathrm{IU} / \mathrm{ml}), 50 \mu \mathrm{l} \mathrm{GSH}(1 \mathrm{mM}), 100 \mu \mathrm{l}$ NADPH $(0.2 \mathrm{mM})$ and $10 \mu \mathrm{l} \mathrm{H}_{2} \mathrm{O}_{2}(0.25 \mathrm{mM})$. The loss of $\mathrm{NADPH}$ was recorded at $340 \mathrm{~nm}$ at room temperature. The absorbance was noted at $340 \mathrm{~nm}$, and GSH-Px activity was assessed by using a molar extinction coefficient of $6.23 \times 10^{3} / \mathrm{M} / \mathrm{cm}$.

$\gamma$-Glutamyl transpeptidase $(\gamma$-GT) The activity of $\gamma$-GT was checked following the scheme of Orlowski et al. [46]. Reaction solution consist of an aliquot of $50 \mu \mathrm{l}$ tissue homogenate supernantant, $250 \mu \mathrm{l}$ of glutamyl nitroanilide $(4 \mathrm{mM}), 250 \mu \mathrm{l}$ of glycyl glycine $(40 \mathrm{mM})$ and $250 \mu \mathrm{l}$ of $\mathrm{MgCl} 2(11 \mathrm{mM})$ which was prepared in $185 \mathrm{mM}$ Tris $\mathrm{HCl}$ buffer at room temperature. After $10 \mathrm{~min}$ of incubation, the reaction was stopped with the addition of $250 \mu \mathrm{l} 25 \%$ trichloro acetic acid a and centrifuge at $2500 \times \mathrm{g}$ for $10 \mathrm{~min}$. The OD of supernatant was determined at $405 \mathrm{~nm}$. Activity of $\gamma$-GT was expressed as $\mathrm{nM}$ nitroaniline formed per min per mg protein by using molar extinction coefficient of $1.75 \times 10^{3} / \mathrm{M} / \mathrm{cm}$.

\section{Oxidative stress biomarkers}

Lipid peroxidation assay (LPO) The analysis of lipid peroxides was done by following protocol of Iqbal and Wright [47]. The reaction mixture consists of $290 \mu \mathrm{l}$ phosphate buffer $(0.1 \mathrm{M}, \mathrm{pH} 7.4), 10 \mu \mathrm{l}$ ferric chloride $(100 \mathrm{mM}), 100 \mu \mathrm{l}$ ascorbic acid $(100 \mathrm{mM})$ and $100 \mu \mathrm{l}$ of homogenate. The reaction mixture was incubated in shaking water bath at $37{ }^{\circ} \mathrm{C}$ for $1 \mathrm{~h}$, and then $500 \mu \mathrm{l}$ trichloroacetic acid (10\%) was added. To end, $500 \mu \mathrm{l}$ thiobarbituric acid $(0.67 \%)$ was added and all the tubes were placed in a water bath to boil for $10 \mathrm{~min}$, and then transferred to crushed ice bath before centrifuging at $2500 \times \mathrm{g}$ for $15 \mathrm{~min}$. The quantity of MDA manufactured in each of the samples was evaluated by measuring the OD of the supernatant at $535 \mathrm{~nm}$ against a reagent blank. The outcomes were expressed as nM MDA/min/ mg tissue at $37{ }^{\circ} \mathrm{C}$ using a molar extinction coefficient of $1.56 \times 10^{5} / \mathrm{M} / \mathrm{cm}$.

Hydrogen peroxide assay Estimation of hydrogen peroxide activity in tissue samples was monitored by method described earlier [48]. $100 \mu \mathrm{l}$ of homogenate was amalgamated with reaction mixture comprising; $500 \mu \mathrm{l}$ phosphate buffer $(0.05 \mathrm{M}, \mathrm{pH} 7), 100 \mu \mathrm{l}$ phenol red $(0.28 \mathrm{nM}), 250 \mu \mathrm{l}$ dextrose $(5.5 \mathrm{nM})$ and horse radish peroxidase (8.5 units) and incubation was done at room temperature for $60 \mathrm{~min} .100 \mu \mathrm{l}$ of $\mathrm{NaOH}(10 \mathrm{~N})$ was added following centrifugation at $800 \times \mathrm{g}$ for $5 \mathrm{~min}$. The absorbance of the supernatant was checked at $610 \mathrm{~nm}$ against reagent blank. Production of $\mathrm{H}_{2} \mathrm{O}_{2}$ was measured as $\mathrm{nM} \mathrm{H}_{2} \mathrm{O}_{2} / \mathrm{min} / \mathrm{mg}$ tissue by using the standard curve of phenol red oxidized by $\mathrm{H}_{2} \mathrm{O}_{2}$.

Nitrite assay For the execution of nitrite assay, Griess reagent was utilized [49]. Briefly, tissue samples (100 mg each) were de-proteinised in $100 \mu \mathrm{l}$ solution comprising $5 \% \mathrm{ZnSO}_{4}$ and $0.3 \mathrm{M} \mathrm{NaOH}$, which were then centrifuged at $6400 \times \mathrm{g}$ for $15-20 \mathrm{~min}$ and supernatant was collected. Griess reagent $(1.0 \mathrm{ml})$ was added to the cuvette, and the spectrophotometer (Smart Spec TM Spectrophotometer) was blanked at wavelength of $540 \mathrm{~nm}$, then the supernatant was added to the cuvette having Griess reagent. Standard curve of sodium nitrite was utilized for the quantification nitrite concentration in cardiac tissues.

\section{Histopathological examination}

Histopathological examination was performed for the assessment of cardiac injuries. Tissue samples from each group were fixed in a fixative containing absolute alcohol 
$(85 \mathrm{ml})$, glacial acetic acid $(5 \mathrm{ml})$ and $40 \%$ formaldehyde $(10 \mathrm{ml})$. After dehydration, tissue samples were fixed in paraffin to prepare blocks for microtomy. Tissues were sectioned 4-5 $\mu \mathrm{m}$ with microtome and stained with hemotoxilin-eosin (H\&E) and were examined under lightmicroscope-(DIALUX $20 \mathrm{~EB}$ ) at 40X.

\section{Statistical analysis}

Data are expressed mean \pm SEM $(n=6)$. One way analysis of variance (ANOVA) followed by Tukey's test was used for analyzing the statistical differences between different treatment groups using Graph pad prism 5 software. Level of significance was set at $p<0.05$.

\section{Results}

Overall appearance, body weight and heart/body weight ratio

Rats were observed throughout the experiment for pain and distress by monitoring variations in food/water intake, mobility, and body weight. Animals looked healthy except the DOX group; in which rats appear feeble and their fur became scruffy. DOX did not cause significant decrease in heart weight/body weight $(\mathrm{HW} / \mathrm{BW})$ ratio, while significant decrease in body weight was noticed in rats treated with DOX alone or in combination with low dose AHE (200 mg/kg b.w dose) compared to control group. Maximum restoration was observed in DOX + AHE (400 mg/kg.b.w) and DOX + Sily (100 mg/ kg b.w) groups as against the DOX group (Table 2). No significant changes in the BW gain or $\mathrm{HW} / \mathrm{BW}$ ratio were observed in rats treated with AHE alone. No mortalities were noticed in any of treatment groups.

\section{Effect of AHE on serum cardiac injury biomarkers}

Figure 1 illustrates the serum cardiac marker enzyme levels in different treatment groups. Activities of serum markers; CK, CKMB, AST and LDH were significantly ( $p$ $<0.0001$ ) higher in DOX inoculated group specifying myocardial injury. AHE ameliorated the toxic effect of DOX in a dose dependent manner and best protective effect was observed at AHE high dose. High dose of AHE showed comparable results as silymarin.

\section{Hematological findings}

AHE $(400 \mathrm{mg} / \mathrm{kg})$ co-treated rats exhibited significant $(p<0.0001)$ improvement in most of the hematological parameters compared to DOX-treated rats (Table 3). These observations were confirmed by increased RBCs, $\mathrm{Hb} \%, \mathrm{PCV}, \mathrm{MCV}, \mathrm{MCH}, \mathrm{MCHC}$ values and platelets counts. However, a significant $(P<0.01)$ reduction in RBCs and platelets counts as well as a significant $(P<0.01)$ increase in lymphocytes counts was recorded in DOX-treated rats compared to control rats.

\section{Effect of AHE on cardiac antioxidant enzyme status}

Antioxidant polyphenolic compounds are indispensable in the reclamation of reactive oxygen species (ROS) and help to maintain cellular equilibrium. In order to characterize the protective effect of AHE; alteration in antioxidant enzyme level were estimated after DOX treatment.

Table 4 demonstrates the protective effect of AHE on phase I antioxidant enzymes of heart i.e., CAT, POD, SOD and QR. In comparison to the control group, the level of CAT, POD, SOD and QR were significantly $(p<0.0001)$ decreased after the DOX inoculation. Co-administration of AHE with DOX restored the level of these enzymes in a dose dependent manner, and at high dose it was statistically similar to that of the silymarin treated group.

Phase II antioxidant enzymes play a vital role in for detoxification of free radicals and synchronize action of different antioxidants is indispensable for maintaining redox balance. DOX-treatment showed significant $(p<0.0001)$ depletion of GSH, $\gamma$-GT, GR, GST, and GPx activity as compared to control animals (Table 5). DOX-induced

Table 2 Effect of DOX and/or AHE treatment on body weight, heart weight and heart /body weight ratio of rats

\begin{tabular}{|c|c|c|c|c|}
\hline \multirow[t]{2}{*}{ Treatment (mg/kg) } & \multicolumn{2}{|c|}{ Body weight (BW)(g) } & \multirow[t]{2}{*}{ Heart weight $(\mathrm{HW})(\mathrm{g})$} & \multirow[t]{2}{*}{ Ratio $\left(\mathrm{HW} / \mathrm{BW} \times 10^{3}\right)$} \\
\hline & Initial & Final & & \\
\hline Control & $219.0 \pm 0.577$ & $250.3 \pm 0.333^{b}$ & $0.501 \pm 0.023$ & 2.00 \\
\hline DOX & $221.3 \pm 0.667$ & $226.3 \pm 0.661^{a}$ & $0.76 \pm 0.021^{a}$ & 3.35 \\
\hline AHE alone & $220.3 \pm 0.667$ & $248.3 \pm 0.671^{b}$ & $0.509 \pm 0.01^{b}$ & 2.04 \\
\hline DOX + AHE (200) & $221.7 \pm 0.882$ & $232.2 \pm 0.611^{\mathrm{a}, \mathrm{b}}$ & $0.651 \pm 0.019^{a * * b * c * *}$ & 2.80 \\
\hline DOX + AHE (400) & $220.3 \pm 0.882$ & $244.7 \pm 0.882^{a, b, c}$ & $0.534 \pm 0.017^{b}$ & 2.18 \\
\hline DOX + Sily & $222.0 \pm 0.577$ & $243.3 \pm 0.333^{\mathrm{a}, \mathrm{b}}$ & $0.541 \pm 0.018^{b}$ & 2.22 \\
\hline
\end{tabular}

Data expressed as mean \pm SEM $(n=6)$

${ }^{a}$ significant difference of final body weight of group Vs. Control group at $p<0.0001$

${ }^{b}$ significant difference of final body weight of group Vs. DOX-treated group at $p<0.0001$

'significant difference of final body weight of DOX + AHE $(200 \mathrm{mg} / \mathrm{kg})$ treated group Vs. DOX + AHE $(400 \mathrm{mg} / \mathrm{kg})$ treated group at $p<0.001$

$*$ ***indicate significance at $p<0.05$ and $p<0.001$. Non-significant difference $(p>0.05)$ was recorded between control and AHE alone treated group in all parameters.

(One way ANOVA followed by Tukey's multiple comparison tests). Sily-Silymarin 

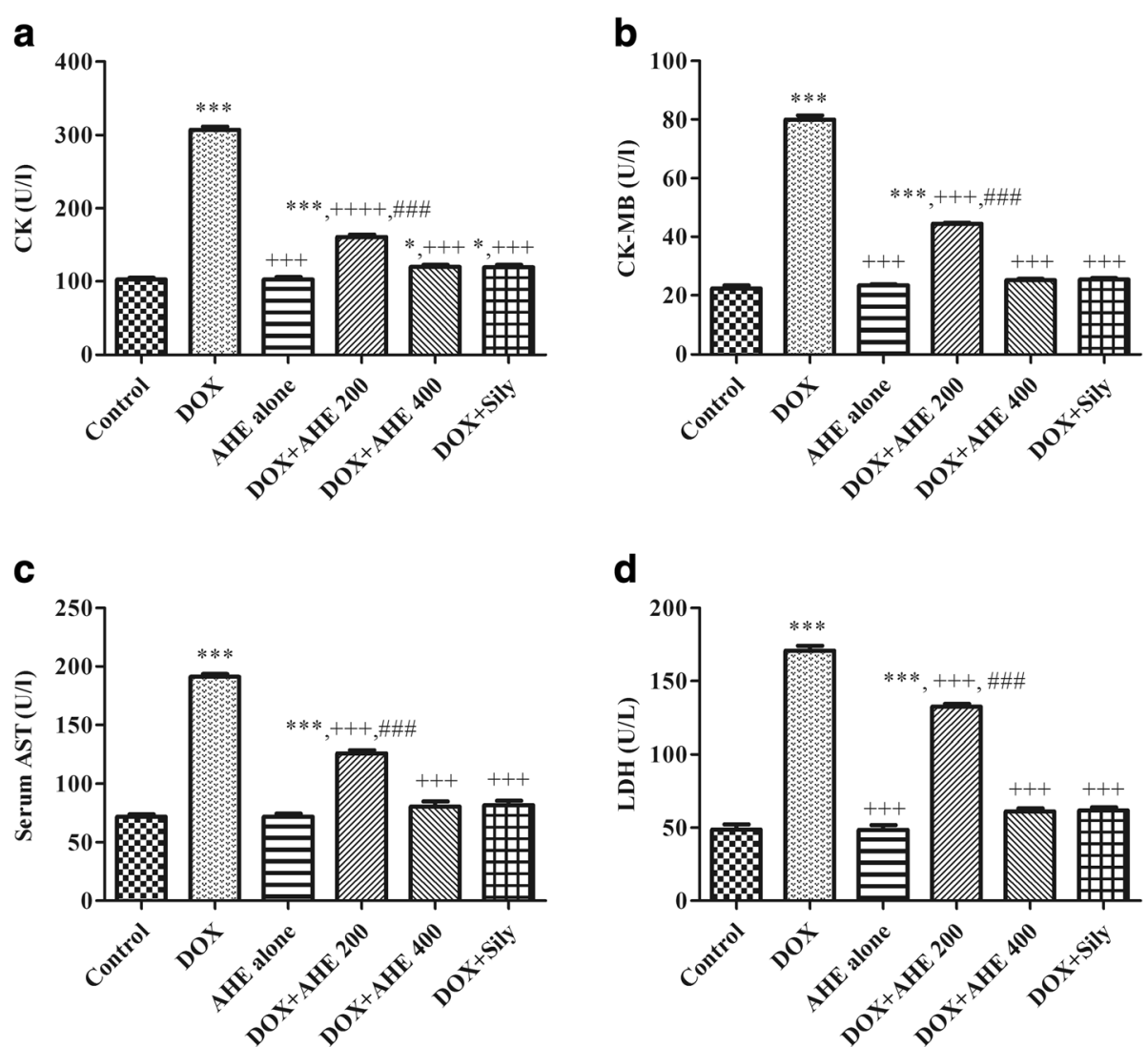

Fig. 1 Effect of AHE treatment on serum markers of cardiac injury. a CK, (b) CK-MB, (c) AST, (d) LDH. Data are represented mean \pm S.E.M $(n=6)$.

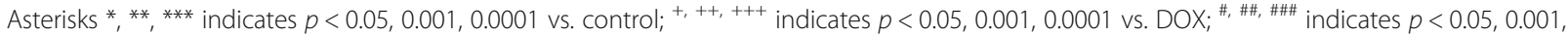
0.0001 vs. AHE $(200 \mathrm{mg} / \mathrm{kg}$ b.w $)$

deterioration in cardiac antioxidant enzyme levels was prevented noticeably with co-treatment of AHE in dose dependent manner. Activity level enzymes at high dose of AHE were statistically similar to the silymarin treated group. AHE alone treatment exhibited non-significant difference in the activity level of phase I and phase II antioxidant enzymes in comparison to control group.

\section{Assessment of cardiac tissue protein content and oxidative stress biomarkers}

Table 6 showed profile of proteins and oxidative stress marker i.e., TBARS, $\mathrm{H} 2 \mathrm{O} 2$ and nitrite content of different groups. Cardiac tissue protein contents were reduced by $\operatorname{DOX}(p<0.0001)$ in comparison to the control group. Animals administered with AHE (400 mg/kg) alone showed an increase in protein contents as compared to the AHE $(200 \mathrm{mg} / \mathrm{kg})+$ DOX, AHE $(400 \mathrm{mg} /$ $\mathrm{kg})+\mathrm{DOX}$ and only DOX group. DOX inoculation markedly increased cardiac tissue levels of MDA, $\mathrm{H}_{2} \mathrm{O}_{2}$ and nitrite contents compared to control group $(p<0.0001)$. Co-administration of AHE substantially prevented the rise in MDA level in a dose dependent manner, and nonsignificant difference was observed at higher dose in comparison to that of the control group. Level of $\mathrm{H}_{2} \mathrm{O}_{2}$ and nitrite content was dropped markedly and at the higher dose of AHE their level was statistically similar to that of the silymarin treated group. However, even at the higher dose of AHE their level was significantly higher against the control group. AHE, when treated in the absence of DOX, non-significant alteration in the level of above mention parameters as compared to control group.

\section{Histopathological examination of heart}

The morphological examination of heart from different trial groups exhibited series of variations from no injury (control group) to mild lesions (AHE + DOX treated groups) to severe damage (DOX group). The control animals showed regular cardiomyocytes histoarchitecture with no visible signs of degenerations, fibrosis or necrosis (Fig. 2). DOX-intoxicated group showed exclusive pathological changes in cardiac tissue morphology showing inflammatory infiltrations, eosinophilic degeneration, necrosis in muscle fibers, hypertrophy of muscle fibers, distortion in blood capillaries, disturbance in the trabeculae of heart, retrogressive lacerations in muscle fibres, vacuolated muscle fibers and interstitial edema. 


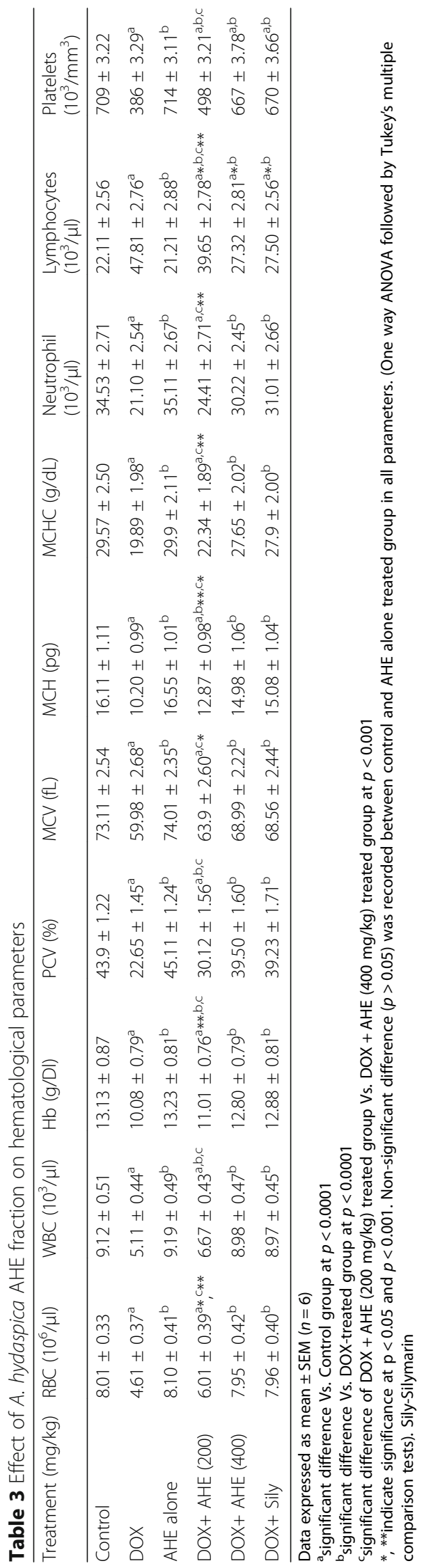


Table 4 Effect of Doxorubicin (DOX) and AHE treatment on cardiac tissue antioxidant enzymes

\begin{tabular}{lllll}
\hline Group & POD (U/min) & SOD (U/mg protein) & CAT (U/min) & QR (nM/min/mg protein) \\
\hline Control & $10.66 \pm 0.538^{\mathrm{b}}$ & $1.146 \pm 0.037^{\mathrm{b}}$ & $15.76 \pm 0.118^{\mathrm{b}}$ & $137.5 \pm 0.735^{\mathrm{b}}$ \\
DOX & $5.970 \pm 0.560^{\mathrm{a}}$ & $0.7845 \pm 0.027^{\mathrm{a}}$ & $9.025 \pm 0.090^{\mathrm{a}}$ & $83.45 \pm 0.416^{\mathrm{a}}$ \\
AHE alone & $10.92 \pm 0.531^{\mathrm{b}}$ & $1.145 \pm 0.049^{\mathrm{b}}$ & $15.66 \pm 0.197^{\mathrm{b}}$ & $137.7 \pm 0.392^{\mathrm{b}}$ \\
DOX+AHE (200) & $8.63 \pm 0.363^{\mathrm{a}, \mathrm{b} * *}$ & $0.9799 \pm 0.027^{\mathrm{b} *}$ & $12.87 \pm 0.297^{\mathrm{a}, \mathrm{b}, \mathrm{d}}$ & $117.6 \pm 0.652^{\mathrm{a}, \mathrm{b}, \mathrm{d}}$ \\
DOX+ AHE (400) & $9.600 \pm 0.3464^{\mathrm{b}}$ & $1.042 \pm 0.025^{\mathrm{b} * *}$ & $14.95 \pm 0.216^{\mathrm{b}, \mathrm{c}}$ & $131.0 \pm 1.621^{\mathrm{a} *, \mathrm{~b}, \mathrm{c}}$ \\
DOX+ Sily & $9.590 \pm 0.3406^{\mathrm{b}}$ & $1.055 \pm 0.053^{\mathrm{b} * *}$ & $14.93 \pm 0.256^{\mathrm{b}}$ & $130.4 \pm 0.7148^{\mathrm{a}, \mathrm{b}}$ \\
\hline
\end{tabular}

Values expressed as mean \pm SEM

a Significance at $p<0.0001$ Vs. control group

${ }^{\mathrm{b}}$ Significance at $p<0.0001 \mathrm{Vs}$. Doxorubicin (DOX) group

'Significance at $p<0.0001$ of DOX + AHE $400 \mathrm{mg} / \mathrm{kg}$ group Vs. DOX + AHE $200 \mathrm{mg} / \mathrm{kg}$ group

${ }^{\mathrm{d}}$ Significance at $p<0.0001$ of AHE co-treatment groups Vs DOX + Sily group

* ${ }^{* *}$ Significant difference at $p<0.05$ and $p<0.001$ respectively. Non-significant difference $(p>0.05)$ was recorded between control and AHE alone treated group

in all parameters. (One way ANOVA followed by Tukey's multiple comparison tests). Sily-Silymarin

Cardiac tissue sections from AHE $(400 \mathrm{mg} / \mathrm{kg}$ b.w $)+$ DOX group reveals myocardium of nearly normal appearance, significantly low occurrence of the degenerations and absence of necrosis, when compared with cardiac tissue sections from rats exposed only to DOX alone. However, AHE 200 mg/kg b.w co treatment group presented some incidence of morphological aberrations viz. irregular direction of cardiomyocytes, occasional interstitial edema, very mild inflammatory cell infiltrations and slight myocardium degenerations. However, the incidence of necrosis was still considerably lower than DOX group. Silymarin treatment showed normal cardiac muscle fibers with mild sign of toxicity in small restricted foci, less capillary dilatation and vacuolar changes in comparison to DOX-alone treated group, and most of the muscle fibers appear as control group indicating protective and comparable effects of AHE high dose treatment to silymarin.

\section{Discussion}

Doxorubicin (DOX) therapy is associated with irreversible and progressive cardiomyopathy that restricted its clinical implication. Oxidative stress has been ascribed as the dominant cause in DOX-induced cardio-toxicity.
Failure of antioxidant defense of cardio-myocytes marks the heart a major target for DOX induced injuriousness [50]. In the literature, it has been studied that antioxidant treatment provides protection against DOX mediated cardiotoxicity [51, 52]. In view of the fact that medicinal plants are being tested for their possible therapeutic potential against ROS induced damages due to their antioxidant potential, the current study was conducted to evaluate the protective potential of polyphenol rich AHE extract against DOX induced myocardial injury.

Detection of cardiac insult, tissue ischemia and myocardial infarction employs estimation of recognized cardiac marker enzymes i.e., Creatine kinase (CK), cardiac creatine kinase MB fraction (CK-MB), AST, ALT, ALP, LDH and cholesterol present in the serum [53, 54]. All of the exemplified parameters are not only demarcated to cardiac tissue except CK and CKMB, their enhanced levels in serum may possibly an indication of noncardiac tissue damages for instance; liver injury. CKMB appear to be the most sensitive and specific markers of myocardial injury, and WHO acknowledged it as a gold standard signal of myocardial impairment [55]. The cardiac cell membrane integrity

Table 5 Effect of Doxorubicin (DOX) and different treatments of AHE on cardiac enzymatic antioxidant levels and GSH profile

\begin{tabular}{|c|c|c|c|c|c|}
\hline Group & GSH ( $\mu \mathrm{M} / \mathrm{g}$ tissue) & GR (nM/min/mg protein) & GST (nM/min/mg protein) & Y-GT (nM/min/mg Protein) & GPx (nM/min/mg Protein) \\
\hline Control & $20.55 \pm 0.280^{b}$ & $154.9 \pm 0.96^{b}$ & $148.6 \pm 0.665^{b}$ & $303.5 \pm 0.811^{b}$ & $122.4 \pm 0.639^{b}$ \\
\hline DOX & $12.36 \pm 0.490^{\mathrm{a}}$ & $108.7 \pm 1.095^{\mathrm{a}}$ & $108.9 \pm 1.105^{\mathrm{a}}$ & $98.54 \pm 1.106^{\mathrm{a}}$ & $63.20 \pm 1.027^{\mathrm{a}}$ \\
\hline AHE alone & $20.66 \pm 0.237^{b}$ & $155.6 \pm 0.439^{b}$ & $148.4 \pm 0.815^{b}$ & $306.9 \pm 0.401^{b}$ & $122.9 \pm 0.285^{b}$ \\
\hline DOX + AHE (200) & $14.37 \pm 0.38^{\mathrm{a}, \mathrm{b} *, \mathrm{~d}}$ & $122.9 \pm 1.14^{\mathrm{a}, \mathrm{b}, \mathrm{d}}$ & $122.8 \pm 0.984^{a, b, d}$ & $188.8 \pm 0.095^{a, b, d}$ & $85.37 \pm 0.540^{a, b, d}$ \\
\hline $\mathrm{DOX}+\mathrm{AHE}(400)$ & $18.59 \pm 0.44^{a *, b, c}$ & $141.2 \pm 1.00^{\mathrm{a}, \mathrm{b}, \mathrm{c}}$ & $140.6 \pm 0.723^{\mathrm{a}, \mathrm{b}, \mathrm{c}}$ & $291.6 \pm 0.69^{a, b, c}$ & $114.1 \pm 0.845^{a, b, c}$ \\
\hline DOX + Sily & $18.77 \pm 0.360^{b}$ & $140.3 \pm 1.55^{\mathrm{a}, \mathrm{b}}$ & $139.2 \pm 0.4623^{a, b}$ & $289.0 \pm 0.68^{a, b}$ & $115.9 \pm 1.290^{\mathrm{a} * *, \mathrm{~b}}$ \\
\hline
\end{tabular}

Values expressed as mean \pm SEM

a Significance at $p<0.0001$ Vs. control group

${ }^{\mathrm{b}}$ Significance at $p<0.0001 \mathrm{Vs}$. Doxorubicin (DOX) group

'Significance at $p<0.0001$ of DOX + AHE $400 \mathrm{mg} / \mathrm{kg}$ group Vs. DOX + AHE $200 \mathrm{mg} / \mathrm{kg}$ group

${ }^{\mathrm{d}}$ Significance at $p<0.0001$ of AHE co-treatment groups Vs DOX + Sily group

$*{ }^{* *}$ Significant difference at $p<0.05$ and $p<0.001$ respectively. Non-significant difference $(p>0.05)$ was recorded between control and AHE alone treated group

in all parameters. (One way ANOVA followed by Tukey's multiple comparison tests). Sily-Silymarin 
Table 6 Effect of Doxorubicin (DOX) and different treatments of AHE on cardiac tissue protein, $\mathrm{H}_{2} \mathrm{O}_{2}$, nitrite content and lipid peroxidation

\begin{tabular}{lllll}
\hline Group & Protein $(\mu \mathrm{g} / \mathrm{mg}$ Tissue $)$ & $\mathrm{H}_{2} \mathrm{O}_{2}(\mathrm{nM} / \mathrm{min} / \mathrm{mg}$ Tissue) & Nitrite (content $\mu \mathrm{M} / \mathrm{ml})$ & TBARS $(\mathrm{nM} / \mathrm{min} / \mathrm{mg}$ protein) \\
\hline Control & $1.638 \pm 0.033^{\mathrm{b}}$ & $1.932 \pm 0.015^{\mathrm{b}}$ & $42.59 \pm 0.552^{\mathrm{b}}$ & $2.874 \pm 0.180^{\mathrm{b}}$ \\
DOX & $1.122 \pm 0.0323^{\mathrm{a}}$ & $5.854 \pm 0.011^{\mathrm{a}}$ & $78.12 \pm 0.499^{\mathrm{a}}$ & $7.575 \pm 0.573^{\mathrm{a}}$ \\
AHE alone & $1.614 \pm 0.015^{\mathrm{b}}$ & $1.911 \pm 0.049^{\mathrm{b}}$ & $41.72 \pm 0.650^{\mathrm{b}}$ & $2.859 \pm 0.086^{\mathrm{b}}$ \\
DOX + AHE (200) & $1.392 \pm 0.036^{\mathrm{a}, \mathrm{b}}$ & $3.950 \pm 0.003^{\mathrm{a}, \mathrm{b}, \mathrm{d}}$ & $66.47 \pm 1.456^{\mathrm{a}, \mathrm{b}, \mathrm{d}}$ & $6.159 \pm 0.091^{\mathrm{a}, \mathrm{b} *, \mathrm{~d}}$ \\
DOX + AHE (400) & $1.490 \pm 0.018^{\mathrm{a} * \mathrm{~b}}$ & $2.719 \pm 0.006^{\mathrm{a}, \mathrm{b}, \mathrm{c}}$ & $49.94 \pm 0.770^{\mathrm{a}, \mathrm{b}, \mathrm{c}}$ & $3.258 \pm 0.167^{\mathrm{b}, \mathrm{c}}$ \\
DOX + Sily & $1.509 \pm 0.027^{\mathrm{b}}$ & $2.645 \pm 0.004^{\mathrm{a}, \mathrm{b}}$ & $50.60 \pm 0.322^{\mathrm{a}, \mathrm{b}}$ & $3.233 \pm 0.151^{\mathrm{b}}$ \\
\hline
\end{tabular}

Values expressed as mean \pm SEM

${ }^{\text {a }}$ Significance at $p<0.0001 \mathrm{Vs}$. control group

${ }^{\mathrm{b}}$ Significance at $p<0.0001 \mathrm{Vs}$. Doxorubicin (DOX) group

'Significance at $p<0.0001$ of DOX + AHE $400 \mathrm{mg} / \mathrm{kg}$ group Vs. DOX + AHE $200 \mathrm{mg} / \mathrm{kg}$ group

${ }^{\mathrm{d}}$ Significance at $p<0.0001$ of AHE co-treatment groups Vs DOX + Sily group

*Significant difference at $p<0.05$ and $p<0.001$ respectively. Non-significant difference $(p>0.05)$ was recorded between control and AHE alone treated group in all parameters. (One way ANOVA followed by Tukey's multiple comparison tests). Sily-Silymarin

loss as a result of free radical mediated lipid peroxidation causing leakage of enzymes [51]. This accounts for the diminished activities of these enzymes in cardiac tissue as these enzymes released into the blood, thus increasing their levels in the serum as a signal of myocyte damage [56, 57].

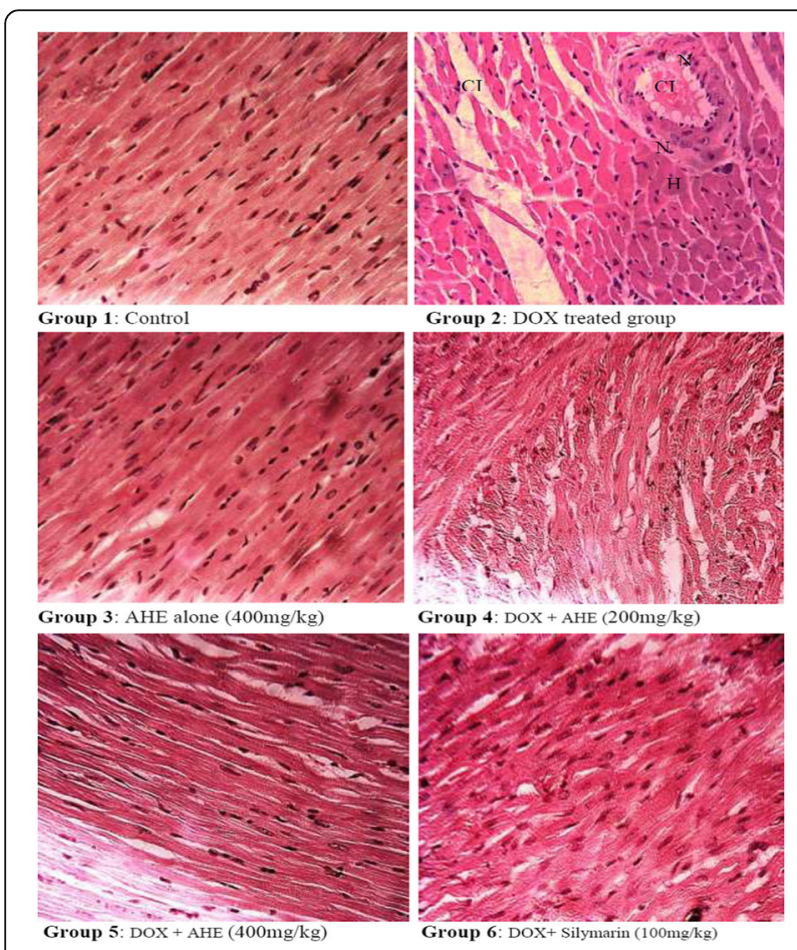

Fig. 2 Histopathological changes induced by Doxorubicin and protective effect of AHE in rat heart (H\&E staining, magnification 40X). Group 1: Cardiac section from control rats showing normal morphology. Group 2: cardiac sections from DOX-treated rats reveal degenerative changes. Group 3: Represents cardiac section from AHE alone treated rats. Group 4: AHE (200 mg/kg b.w) showed reduced degenerations. Group 5: AHE (400 mg/kg b.w) results in significant protection against DOX induced cardiac injury. Group 6: Showed protective effect of Silymarin treatment. AHE: A.hydaspica ethyl acetate fraction, DOX: Doxorubicin, H: hypertrophy, N: necrosis, Cl: cellular infiltrations
DOX induced excessive elevation of CK, CKMB and $\mathrm{LDH}$ concentration in the serum as compared to control is an indicator of myocardial injury. Our outcomes were consistent with the observations of EL-Sayed and colleagues demonstrating that DOX treatment predominantly elevated serum CKMB, CK and LDH activity; the most sensitive biomarkers of myocardial cell injury [58]. The mechanism involves in the release of these marker enzymes seems to be oxidative damage to heart tissue and consequent release of its insides substances into the circulation. Enhanced production of free radicals, especially superoxide anion radicals could enhance the inflammatory cascade in the cell wall and might result in atrial endothelial dysfunction. Beside these ventricular alterations, continuing myocyte degeneration and abridged coronary reserve might be the causes of enzyme leakage [59]. Normalization of the serum content of CK, CK-MB, AST and LDH in experimental groups treated with AHE co-treatment group's shows improved cardiac function in DOX intoxicated groups hence, indicates the cardio-protective potential of $A$. hydaspica. The results were comparable with standard Silymarin. Presence of gallic acid in AHE might attribute to the protective effect as previous studies indicated that gallic acid markedly brought down serum cardiac and lipid biomarkers in DOX treated rats [60]. Our outcomes are similar to previous findings on protective effect of plant extracts against DOX induced cardiotoxicity [58]. The current serological findings have an outstanding relationship with histological investigation of cardiac tissue of rat.

Hematopoietic system is a rational indicator to delineate the physical condition. Measurement of cellular component of blood is important in establishing the body's functional status as a result of exposure to toxicants [61]. The present study indicated that cotreatment with AHE had effectively ameliorated the hematological anomalies induced by DOX in a dose dependent manner. The deleterious influence of DOX 
on blood parameters was verified by the significant drop in $\mathrm{RBCs}, \mathrm{Hb}$ and platelets counts with consequent drop in the values of $\mathrm{MCV}, \mathrm{MCH}, \mathrm{MCHC}$ and PCV. DOX intoxication might lead to anemia as a result of either altered activity of hematopoietic tissues, impaired erythropoiesis, and/or defective iron metabolism [62]. Furthermore chronic administration of DOX induced a reduction in the number of platelets and an increase in the number lymphocytes in the blood of rats. Previous studies also confirm doxorubicin-mediated thrombocytopenia via cytotoxic effect of DOX on platelets. DOX induced bone marrow toxicity has been suggested as underlying cause of reduced platelet counts. Furthermore reactive oxygen species (ROS) generation, decreased glutathione levels and consequent protein thiol depletion were exposed to be the cause of the DOX-persuaded platelet cytotoxicity [63]. However, the increase in the lymphocytes number might be the result of inflammation during DOX treatment. AHE was found to have beneficial effects against DOX-persuaded deterioration in most of hematological parameters and RBCs indices as it increased number of RBCs and $\mathrm{Hb}$ concentration and other hematological parameters about to normal levels. Our results are in line with previous studies indicating the ameliorating potential of Acacia species on an increase in erythropoiesis and other hematological parameters due to their immune-stimulatory properties $[64,65]$. The ameliorative effect of AHE might be due to reduction of lipid peroxidation level with subsequent prevention of free radicals induced damage through its antioxidant activity achieved by its active compounds.

Antioxidant enzymes, i.e. SOD, POD, CAT, QR, GSH, GPx, $\gamma$ GT, GST provides defense against oxidative stress mediated tissue injury. GSH in cellular defense system has the conjugating aptitude with free radicals and metabolites, consequently alleviating the membranes from the damaging influences of lipid peroxides. Previous study demonstrated that cellular GSH decrease is directly linked with LPO caused by lethal agents [66]. The rise in MDA level (LPO product) could be ascribed to DOX persuaded production of oxygen free radicals that arouse widespread tissue mutilations, countering with membrane proteins, lipids and nucleic acids $[67,68]$. The deterioration in GSH level in DOX-treated rats ensued LPO augmentation thus confirming cardiotoxicity [69]. The outcomes of the current study are in harmony with earlier findings, illustrating that myocardial antioxidant protection system was functioning at a lower rate apart from the higher level of oxidative stress in DOX intoxicated cardiotoxicity [51, 70]. In the current investigation, the noticeable decrease in cardiac tissue antioxidant enzyme levels and increase in oxidative stress markers (MDA, $\mathrm{NO}$ and $\mathrm{H}_{2} \mathrm{O}_{2}$ ) besides decreased in cardiac tissue protein content are confirmations of the oxidative stress instigated by DOX treatment. It was observed that AHE high dose co-treatment was able to antagonize DOX induced diminution of antioxidant enzymes, and reverse the levels near normal, and its efficacy was comparable to the silymarin treated group. Analogous to current outcomes, previous research reported that silymarin treatment before ischemic-reperfusion-prompted myocardial infarction maintained the cardiac marker enzymes compared with isoproterenol-administered rats [71], similar protective effect of silymarin against $\mathrm{CP}$ induced cardiotoxicity was also reported previously [51]. The protective potential of AHE attributes to the presence of phenolic and flavonoid compounds in AHE [26]. As gallic acid and catechin are major polyphenols in AHE and previous studies on gallic acid affirms that its mechanism of protection is through the restoration of the endogenous antioxidant system by scavenging the reactive oxygen species [60]. A similar study on catechin proves that It protect DOX induced cardiotoxicity in rats in a dose dependent manner [72]. Catechin has anti-inflammatory and anti-oxidative effects against Adriamycin induced cardiotoxicity, which results from intense cardiac oxidative stress and inflammation [73]. The most common mechanism of action for almost all phenolic compounds is inhibition of oxidative stress by scavenging free radicals and enhancing cellular antioxidant defense mechanisms in cardiomyocytes [74, 75]. In current finding, the obvious increase in tissue antioxidant status, decrease in lipid peroxidation and other oxidative stress markers suggest that protection afforded by AHE may be mediated through the modulation of cellular antioxidant enzyme levels and by averting the generation of free radicals in myocardial cells.

Histopathology showed myocardial atrophy, nuclear condensation of chromosomes and cytoplasmic vacuoles in DOX intoxicated cardiac tissues. AHE in a dose depend manner demonstrated considerable prevention in the structural changes in cardiomyocytes of DOXintoxicated animals. DOX treatment induced noticeable fatty obstruction in the blood vessel and clearance of cytoplasm with foamy appearance while nuclear deterioration was also seen in some areas. All these morphological deteriorations caused by DOX were considerably reverted by AHE co-treatments. The protective effect of AHE is comparable to silymarin treatment. Analogous findings were demonstrated by the previous study illustrating that silymarin suppressed the adriamycin induced cardiotoxicity in male albino rats [76]. The protective effect of AHE might be due to its antioxidant potential, AHE protective cardiomyocytes damages by augmenting tissue antioxidant status and inhibiting oxidative stress mediated free radical generation. Figure 3 summarizes the possible mechanism of AHE protective effect against DOX mediated cardiotoxicity. Previous studies have also authenticates the beneficial effect of 


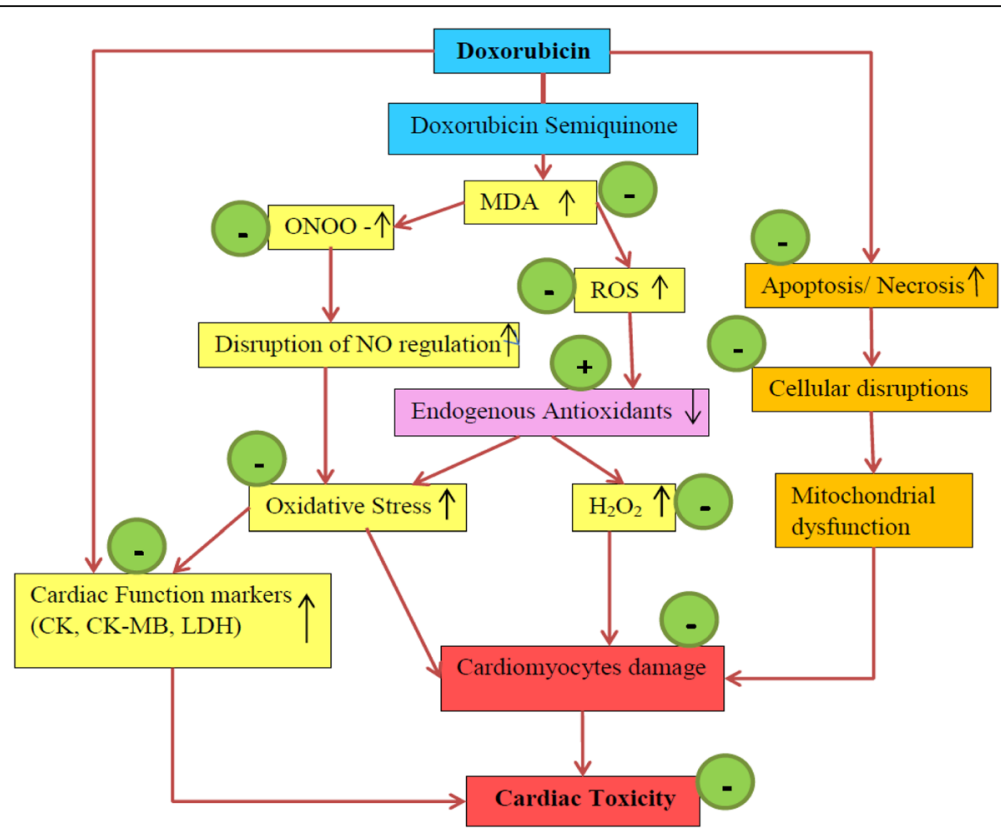

Fig. 3 Hypothetical pathway describing the possible underlying mechanism of DOX induced cardiotoxicity and protective effect of AHE. Green circles indicate points of AHE treatment effect, - sign indicates inhibition and + sign indicates augmentation

antioxidant in doxorubicin or adriamycin induced myocardial damage [77, 78]. Du and Lou, 2008 illustrated that the cardiovascular protective effects of grape seed against DOX induce toxicity is believed to be ascribed to its antioxidant properties. Grape seed polyphenols, catechin and proanthocyanidin $\mathrm{B} 4\left(\mathrm{PC} \mathrm{B}_{4}\right)$ pretreatment would protect cardiomyocytes against doxorubicin-induced toxicity by decreasing ROS generation, preventing DNA damage, regulating the expression and signaling pathway of pro-apoptotic and anti-apoptotic proteins [79]. Similarly Singh and his coworkers reported the cardio-protective effect of butanol fraction of Terminalia arjuna bark against DOX induced morphological alteration by alleviating morphological changes and decreasing oxidative stress [80]. The observed protective effect may be accredited to the distinct or synergistic effect of bioactive phytochemicals present in the AHE fraction.

\section{Conclusion}

The implication of oxidative stress in the etiology of chemotherapeutic drug induced cardiovascular ailments suggests that medicinal plants possessing antioxidant potential represents a promising avenue for treatment. Strategies for the intervention and prevention of cardiovascular illnesses require an understanding of the basic mechanism by which the prophylactic agents may potentially prevent the toxic effects. The current study used chronic model of DOX cardiotoxicity in trial experiment and the results shows AHE may be beneficial for DOX-induced cardiotoxicity by ameliorating oxidative stress. However, this basic research needs to be further confirmed in a more clinically relevant model to explicate the mechanism and develop strategies in prevention against DOX-induced cardiotoxicity.

\section{Abbreviations}

AHE: Acacia hydaspica ethyl-acetate extract; AST: Aspartate aminotransferase; CAT: Catalase; CK: Creatine kinase; CK-MB: Cardiac creatine kinase MB fraction: DOX: Doxorubicin; GPx: Glutathione peroxidase; GSH: Reduced glutathione; GST: Glutathione s transferase; $\mathrm{H}_{2} \mathrm{O}_{2}$ : Hydrogen peroxide; $\mathrm{Hb}$ : Hemoglobin; LDH: Lactate dehydrogenase; LPO: Lipid peroxidation; MCH: Mean corpuscle hemoglobin; MCHC: Mean corpuscle hemoglobin concentration; MCV: Mean corpuscle volume; MDA: Malondialdehyde; NO: Nitric oxide; PCV: Packed cell volume; POD: Peroxidase; QR: Quinone reductase; RBCs: Red blood cells; ROS: Reactive oxygen species; SOD: Superoxide dismutase; $\gamma$ GT: $\gamma$-Glutamyl transpeptidase

\section{Acknowledgements}

We acknowledge Higher Education Commission (HEC) of Pakistan for awarding indigenous scholarship for PHD research to the first author. The author K.M. Batoo is thankful to the Deanship of Scientific Research at King Saud University for its funding through the Research Group Project no. RG-1437-030.

\section{Funding}

The project was partially funded by the Higher Education Commission (HEC) of Pakistan by awarding indigenous scholarship to the first author. We are thankful to the Deanship of Scientific Research at King Saud University for its funding through the Research Group Project no. RG-1437-030.

\section{Availability of data and materials}

All data generated or analysed during this study are included in this published article.

\section{Authors' contributions}

TA made significant contributions to conception, design, experimentation, acquisition and interpretation of data and writing of manuscript. SR, KMB and MRK made substantial contribution in interpretation of data and revising 
the manuscript for intellectual content. All authors read and approved the final manuscript.

\section{Ethics approval}

This study makes use of rats, and the experimental protocol for the use of animal was approved (Bch\#0256) by the ethical board of Quaid-i-Azam University, Islamabad Pakistan.

\section{Consent for publication}

Not applicable

\section{Competing interests}

The authors declare that they have no competing interests.

\section{Publisher's Note}

Springer Nature remains neutral with regard to jurisdictional claims in published maps and institutional affiliations.

\section{Author details}

${ }^{1}$ Department of Biochemistry, Faculty of Biological Sciences, Quaid-i-Azam University, Islamabad, Pakistan. ${ }^{2}$ Department of Animal Sciences, Faculty of Biological Sciences, Quaid-i-Azam University, Islamabad, Pakistan. ${ }^{3}$ Department of Community Health Sciences, College of Applied Medical Sciences, King Saud University, Riyadh, Kingdom of Saudi Arabia. ${ }^{4}$ King Abdullah Institute for Nanotechnology, King Saud University, P.O.Box 2455, Riyadh 11451, Kingdom of Saudi Arabia.

\section{Received: 24 April 2017 Accepted: 15 December 2017}

\section{Published online: 29 December 2017}

\section{References}

1. Aleman BM, Moser EC, Nuver J, Suter TM, Maraldo MV, Specht L, Vrieling C, Darby SC. Cardiovascular disease after cancer therapy. Eur J Cancer Suppl. 2014;12(1):18-28

2. Blum RH, Carter SK. Adriamycin: a new anticancer drug with significant clinical activity. Ann Intern Med. 1974;80(2):249-59.

3. Chang Y-L, Lee H-J, Liu S-T, Lin Y-S, Chen T-C, Hsieh T-Y, Huang H-S, Huang S-M. Different roles of p53 in the regulation of DNA damage caused by 1 , 2-heteroannelated anthraquinones and doxorubicin. Int J Biochem Cell Biol. 2011:43(12):1720-8.

4. Sahna E, Parlakpinar H, Ozer MK, Ozturk F, Ozugurlu F, Acet A. Melatonin protects against myocardial doxorubicin toxicity in rats: role of physiological concentrations. J Pineal Res. 2003;35(4):257-61.

5. Mohan M, Kamble S, Gadhi P, Kasture S. Protective effect of Solanum Torvum on doxorubicin-induced nephrotoxicity in rats. Food Chem Toxicol. 2010;48(1):436-40.

6. Thippeswamy A, Shirodkar A, Koti B, Sadiq AJ, Praveen D, Swamy AV, Patil M. Protective role of Phyllantus niruri extract in doxorubicin-induced myocardia toxicity in rats. Indian J Pharmacol. 2011:43(1):31.

7. Injac R, Perse M, Cerne M, Potocnik N, Radic N, Govedarica B, Djordjevic A Cerar A, Strukelj B. Protective effects of fullerenol C $60(\mathrm{OH}) 24$ agains doxorubicin-induced cardiotoxicity and hepatotoxicity in rats with colorectal cancer. Biomaterials. 2009:30(6):1184-96.

8. Yilmaz S, Atessahin A, Sahna E, Karahan I, Ozer S. Protective effect of lycopene on adriamycin-induced cardiotoxicity and nephrotoxicity. Toxicology. 2006; 218(2):164-71

9. Steinherz LJ, Steinherz PG, Tan CT, Heller G, Murphy ML. Cardiac toxicity 4 to 20 years after completing anthracycline therapy. JAMA. 1991;266(12): 1672-7.

10. Dudka J, Burdan F, Korga A, Dyndor K, Syroka I, Zieba J, Lewkowicz D Korobowicz-Markiewicz A. The diagnosis of anthracycline-induced cardiac damage and heart failure. Postepy Hig Med Dosw (Online). 2008;63:225-33.

11. Feola M, Garrone O, Occelli M, Francini A, Biggi A, Visconti G, Albrile F, Bobbio M, Merlano M. Cardiotoxicity after anthracycline chemotherapy in breast carcinoma: effects on left ventricular ejection fraction, troponin I and brain natriuretic peptide. Int J Cardiol. 2011;148(2):194-8.

12. Minotti G, Menna P, Salvatorelli E, Cairo G, Gianni L. Anthracyclines: molecular advances and pharmacologic developments in antitumor activity and cardiotoxicity. Pharmacol Rev. 2004;56(2):185-229.

13. Korga A, Dudka J, Burdan F, Sliwinska J, Mandziuk S, Dawidek-Pietryka K. The redox imbalance and the reduction of contractile protein content in rat hearts administered with L-thyroxine and doxorubicin. Oxidative Med Cell Longev. 2012;2012:681367.

14. Xu MF, Tang PL, Qian ZM, Ashraf M. Effects by doxorubicin on the myocardium are mediated by oxygen free radicals. Life Sci. 2001:68(8):889-901.

15. Torres VM, Simic VD. Doxorubicin-induced oxidative injury of cardiomyocytes-do we have right strategies for prevention? InCardiotoxicity of oncologic treatments 2012. InTech. ISBN 978-953-51-0273-1. 2012.

16. Tapas AR, Sakarkar D, Kakde R. Flavonoids as nutraceuticals: a review. Trop J Pharm Res. 2008;7(3):1089-99.

17. Soobrattee MA, Neergheen VS, Luximon-Ramma A, Aruoma Ol, Bahorun T. Phenolics as potential antioxidant therapeutic agents: mechanism and actions. Mutat Res. 2005;579(1):200-13.

18. Aydin B, Unsal M, Sekeroglu ZA, Gülbahar Y. The antioxidant and antigenotoxic effects of Pycnogenol ${ }^{\oplus}$ on rats treated with cisplatin. Biol Trace Elem Res. 2011; 142(3):638-50.

19. Lee CK, Son SH, Park KK, Park JHY, Lim SS, Kim SH, Chung WY. Licochalcone a inhibits the growth of colon carcinoma and attenuates Cisplatin-induced toxicity without a loss of chemotherapeutic efficacy in mice. Basic Clin Pharmacol Toxicol. 2008:103(1):48-54.

20. Seigler DS. Phytochemistry of Acacia-Sensu Lato. Biochem Syst Ecol. 2003; 31(8):845-73.

21. Sakthivel K, Kannan N, Angeline A, Guruvayoorappan C. Anticancer activity of Acacia Nilotica (L.) wild. Ex. Delile Subsp. Indica against Dalton's ascitic lymphoma induced solid and ascitic tumor model. Asian Pac J Cancer Prev. 2012;13(8):3989-95.

22. Duarte MR, Wolf S. Anatomical characters of the phyllode and stem of Acacia Podalyriifolia a. Cunn. Ex G. Don (Fabaceae). Rev Bras. 2005;15(1):71-6.

23. Chakrabarty T, Gangopadhyay M. The genus acacia P. Miller (Leguminosae: Mimosoideae) in India. J Econ Taxon Bot. 1996;20(3):599-633.

24. Afsar T, Khan MR, Razak S, Ullah S, Mirza B. Antipyretic, anti-inflammatory and analgesic activity of Acacia Hydaspica R. Parker and its phytochemical analysis. BMC Complement Altern Med. 2015;15(1):136.

25. Afsar T, Razak S, Khan MR, Almajwal A. Anti-depressant and anxiolytic potential of Acacia Hydaspica R. Parker aerial parts extract: modulation of brain antioxidant enzyme status. BMC Complement Altern Med. 2017;17(1):228.

26. Afsar T, Razak S, Khan MR, Mawash S, Almajwal A, Shabir M, Haq IU. Evaluation of antioxidant, anti-hemolytic and anticancer activity of various solvent extracts of Acacia Hydaspica R. Parker aerial parts. BMC Complement Altern Med. 2016;16:258.

27. Afsar T, Trembley JH, Salomon CE, Razak S, Khan MR, Ahmed K. Growth inhibition and apoptosis in cancer cells induced by polyphenolic compounds of Acacia Hydaspica: involvement of multiple signal transduction pathways. Sci Rep. 2016;6:23077.

28. Ojha S, Al Taee H, Goyal S, Mahajan UB, Patil CR, Arya D, Rajesh M. Cardioprotective potentials of plant-derived small molecules against doxorubicin associated Cardiotoxicity. Oxidative Med Cell Longev. 2016: 2016:5724973.

29. Elderbi MA, Mohamed A-WH, Hadi A-HA, Dabobash MD. Potential protective effect of gum Arabic against doxorubicin-induced Cardiotoxicity in Wistar albino rats. Int J Pharm Sci Res. 2014;5(3):1023.

30. Zhao X, Zhang J, Tong N, Chen Y, Luo Y. Protective effects of berberine on doxorubicin-induced hepatotoxicity in mice. Biol Pharm Bull. 2012;35(5):796-800.

31. Oda SS, El-Ashmawy IM. Protective effect of silymarin on mercury-induced acute nephro-hepatotoxicity in rats. Glob Vet. 2012:9(4):376-83.

32. Guideline OO. 425: acute oral toxicity-up-and-down procedure. OECD Guidelines for the Testing of Chemicals. 2001:2:12-6.

33. Irwin S. Comprehensive observational assessment: la. A systematic, quantitative procedure for assessing the behavioral and physiologic state of the mouse. Psychopharmacology. 1968;13(3):222-57.

34. Mensah A, Mireku E, Mensah M, Amponsah I. Some neurological effects of the ethanolic stem bark extract of Cussonia bancoensis Aubrev and Pellgr (Araliaceae). J Pharmacognosy Phytochemistry. 2014;2(6):101-6.

35. van Acker FA, van Acker SA, Kramer K, Haenen GR, Bast A, van der Vijgh WJ. 7-monohydroxyethylrutoside protects against chronic doxorubicin-induced cardiotoxicity when administered only once per week. Clin Cancer Res. 2000;6(4):1337-41.

36. Jalali AS, Hasanzadeh S. Crataegus Monogyna fruit aqueous extract as a protective agent against doxorubicin-induced reproductive toxicity in male rats. Avicenna J Phytomed. 2013:3(2):159.

37. Sakr SA, Mahran HA, Lamfon HA. Protective effect of ginger (Zingiber Officinale) on adriamycin-induced hepatotoxicity in albino rats. J Med Plant Res. 2011:5(1): $133-40$. 
38. Lowry OH, Rosebrough NJ, Farr AL, Randall RJ. Protein measurement with the Folin phenol reagent. J Biol Chem. 1951;193(1):265-75.

39. Chance B, Maehly A. Assay of catalases and peroxidases. Methods Biochem Anal. 1954;1:357-424.

40. Kakkar P, Das B, Viswanathan P. A modified spectrophotometric assay of superoxide dismutase. Indian J Biochem Biophys. 1984;21(2):130-2.

41. Benson AM, Hunkeler MJ, Talalay P. Increase of NAD (P) H: quinone reductase by dietary antioxidants: possible role in protection against carcinogenesis and toxicity. Proc Natl Acad Sci. 1980;77(9):5216-20.

42. Jollow D, Mitchell J, Zampaglione N, Gillette J. Bromobenzene-induced liver necrosis. Protective role of glutathione and evidence for 3, 4-bromobenzene oxide as the hepatotoxic metabolite. Pharmacology. 1974;11(3):151-69.

43. Habig WH, Pabst MJ, Jakoby WB. Glutathione S-transferases the first enzymatic step in mercapturic acid formation. J Biol Chem. 1974;249(22):7130-9.

44. Carlberg I, Mannervik B. Purification and characterization of the flavoenzyme glutathione reductase from rat liver. J Biol Chem. 1975;250(14):5475-80.

45. Mohandas J, Marshall JJ, Duggin GG, Horvath JS, Tiller DJ. Differential distribution of glutathione and glutathione-related enzymes in rabbit kidney: possible implications in analgesic nephropathy. Biochem Pharmacol. 1984;33(11):1801-7.

46. Orlowski M, Sessa G, Green JP. Y-Glutamyl transpeptidase in brain capillaries: possible site of a blood-brain barrier for amino acids. Science. 1974; 184(4132):66-8.

47. Iqbal S, Bhanger M, Anwar F. Antioxidant properties and components of some commercially available varieties of rice bran in Pakistan. Food Chem. 2005;93(2):265-72.

48. Pick E, Mizel D. Rapid microassays for the measurement of superoxide and hydrogen peroxide production by macrophages in culture using an automatic enzyme immunoassay reader. J Immunol Methods. 1981;46(2):211-26.

49. Green LC, Wagner DA, Glogowski J, Skipper PL, Wishnok JS, Tannenbaum SR. Analysis of nitrate, nitrite, and [15 N] nitrate in biological fluids. Anal Biochem. 1982;126(1):131-8.

50. Fadillioglu E, Oztas E, Erdogan H, Yagmurca M, Sogut S, Ucar M, Irmak MK. Protective effects of caffeic acid phenethyl ester on doxorubicin-induced cardiotoxicity in rats. J Appl Toxicol. 2004;24(1):47-52.

51. El-Awady E-SE, Moustafa YM, Abo-Elmatty DM, Radwan A. Cisplatin-induced cardiotoxicity: mechanisms and cardioprotective strategies. Eur J Pharmacol. 2011;650(1):335-41.

52. Dudka J, Gieroba R, Korga A, Burdan F, Matysiak W, Jodlowska-Jedrych B, Mandziuk S, Korobowicz E, Murias M. Different effects of resveratrol on dose-related doxorubicin-induced heart and liver toxicity. Evid Based Complement Alternat Med. 2012;2012:606183.

53. Chrostek L, Szmitkowski M. Enzymatic diagnosis of alcoholism-induced damage of internal organs. Psychiatr Pol. 1988;23(5-6):353-60.

54. Khan MR, Haroon J, Khan RA, Bokhari J, Rashid U. Prevention of KBrO3-induced cardiotoxicity by Sonchus Asper in rat. J Med Plants Res. 2011;5(12):2514-20.

55. Adams JE, Sicard GA, Allen BT, Bridwell KH, Lenke LG, Davila-Roman VG, Bodor GS, Ladenson JH, Jaffe AS. Diagnosis of perioperative myocardial infarction with measurement of cardiac troponin I. N Engl J Med. 1994; 330(10):670-4

56. Kurian GA, Philip S, Varghese T. Effect of aqueous extract of the Desmodium Gangeticum DC root in the severity of myocardial infarction. J Ethnopharmacol. 2005;97(3):457-61.

57. Rajadurai $M$, Prince PSM. Preventive effect of naringin on cardiac markers, electrocardiographic patterns and lysosomal hydrolases in normal and isoproterenol-induced myocardial infarction in Wistar rats. Toxicology. 2007;230(2):178-88.

58. El-Sayed EM, El-azeem ASA, Afify AA, Shabana MH, Ahmed HH. Cardioprotective effects of Curcuma Longa L. extracts against doxorubicin-induced cardiotoxicity in rats. J Med Plants Res. 2011;5(17):4049-58.

59. Potluri S, Ventura HO, Mulumudi M, Mehra MR. Cardiac troponin levels in heart failure. Cardiol Rev. 2004;12(1):21-5.

60. Kulkarni J, Swamy AV. Cardioprotective effect of gallic acid against doxorubicininduced myocardial toxicity in albino rats. Indian J Health Sci Biomed Res (KLEU). 2015;8(1):28.

61. Joshi P, Bose M, Harish D. Haematological changes in the blood of Clarias Batrachus exposed to mercuric chloride. J Ecotoxicol Environ Monit. 2002; 12(2):119-22.

62. Al-Harbi M, Al-Gharably NM, Al-Shabanah OA, Al-Bekairi AM, Osman AMM, Tawfik HN. Prevention of doxorubicin-induced myocardial and haematological toxicities in rats by the iron chelator desferrioxamine. Cancer Chemother Pharmacol. 1992;31(3):200-4.
63. Kim EJ, Lim KM, Kim KY, Bae ON, Noh JY, Chung SM, Shin S, Yun YP, Chung $J H$. Doxorubicin-induced platelet cytotoxicity: a new contributory factor for doxorubicin-mediated thrombocytopenia. J Thromb Haemost. 2009;7(7): 1172-83.

64. Adewale AL. Evaluation of Root Extract of Acacia nilotica on Haematological and Lipid Profile in Rats. Eur J Med Plants. 2016;17(4):1-7.

65. Sakthivel K, Guruvayoorappan C. Acacia Ferruginea inhibits cyclophosphamideinduced immunosuppression and urotoxicity by modulating cytokines in mice. J Immunotoxicol. 2015;12(2):154-63.

66. Kyle ME, Nakae D, Sakaida I, Serroni A, Farber JL. Protein thiol depletion and the killing of cultured hepatocytes by hydrogen peroxide. Biochem Pharmacol. 1989;38(21):3797-805.

67. Nicolson GL, Conklin KA. Reversing mitochondrial dysfunction, fatigue and the adverse effects of chemotherapy of metastatic disease by molecular replacement therapy. Clin Exp Metastasis. 2008;25(2):161-9.

68. Satoh M, Kashihara N, Fujimoto S, Horike H, Tokura T, Namikoshi T, Sasaki T, Makino $\mathrm{H}$. A novel free radical scavenger, edarabone, protects against cisplatin-induced acute renal damage in vitro and in vivo. J Pharmacol Exp Ther. 2003;305(3):1183-90.

69. Karthikeyan K, Bai BS, Devaraj SN. Cardioprotective effect of grape seed proanthocyanidins on isoproterenol-induced myocardial injury in rats. Int J Cardiol. 2007:115(3):326-33.

70. Zarei M, Javarappa KK, Zarei M, Baker S. Cardioprotective effect of the root extract of Hemidesmus indicus against doxorubicin-induced oxidative stress in mice. Pharm Lett. 2013;5(1):334-9.

71. Rao PR, Viswanath RK. Cardioprotective activity of silymarin in ischemiareperfusion-induced myocardial infarction in albino rats. Exp Clin Cardiol. 2007;12(4):179.

72. Kozluca O, Olcay E, Sürücü S, Güran Z, Kulaksiz T, Üskent N. Prevention of doxorubicin induced cardiotoxicity by catechin. Cancer Lett. 1996;99(1):1-6.

73. El-Aziz TAA, Mohamed RH, Pasha HF, Abdel-Aziz HR. Catechin protects against oxidative stress and inflammatory-mediated cardiotoxicity in adriamycintreated rats. Clin Exp Med. 2012;12(4):233-40.

74. Nimse SB, Pal D. Free radicals, natural antioxidants, and their reaction mechanisms. RSC Adv. 2015:5(35):27986-8006.

75. Du Y, Guo H, Lou H. Grape seed polyphenols protect cardiac cells from apoptosis via induction of endogenous antioxidant enzymes. J Agric Food Chem. 2007;55(5):1695-701.

76. El-Shitany NA, El-Haggar S, El-Desoky K. Silymarin prevents adriamycin-induced cardiotoxicity and nephrotoxicity in rats. Food Chem Toxicol. 2008;46(7):2422-8.

77. Morishima I, Matsui H, Mukawa H, Hayashi K, Toki Y, Okumura K, Ito T, Hayakawa T. Melatonin, a pineal hormone with antioxidant property, protects against adriamycin cardiomyopathy in rats. Life Sci. 1998;63(7):511-21.

78. Rašković A, Stilinović N, Kolarović J, Vasović V, Vukmirović S, Mikov M. The protective effects of silymarin against doxorubicin-induced cardiotoxicity and hepatotoxicity in rats. Molecules. 2011;16(10):8601-13.

79. Du Y, Lou H. Catechin and proanthocyanidin B4 from grape seeds prevent doxorubicin-induced toxicity in cardiomyocytes. Eur J Pharmacol. 2008; 591(1):96-101.

80. Singh G, Singh AT, Abraham A, Bhat B, Mukherjee A, Verma R, Agarwal SK, Jha S, Mukherjee R, Burman AC. Protective effects of Terminalia Arjuna against doxorubicin-induced cardiotoxicity. J Ethnopharmacol. 2008;117(1):123-9.

\section{Submit your next manuscript to BioMed Central and we will help you at every step:}

- We accept pre-submission inquiries

- Our selector tool helps you to find the most relevant journal

- We provide round the clock customer support

- Convenient online submission

- Thorough peer review

- Inclusion in PubMed and all major indexing services

- Maximum visibility for your research

Submit your manuscript at www.biomedcentral.com/submit 